\title{
Tripodal Phosphine Oxide Ligand with Tetrazole Functionality
}

\author{
T. V. Baulina ${ }^{a, *}$, I. Yu. Kudryavtsev ${ }^{a}$, O. V. Bykhovskaya ${ }^{a}$, M. P. Pasechnik ${ }^{a}$, \\ L. V. Anikina ${ }^{a}$, A. V. Vologzhanina ${ }^{a}$, V. A. Kochmarik ${ }^{a}$, and V. K. Brel ${ }^{a}$ \\ ${ }^{a}$ Nesmeyanov Institute of Organoelement Compounds of the Russian Academy of Sciences, Moscow, 119991 Russia \\ *e-mail: zaq@ineos.ac.ru
}

Received July 31, 2021; revised July 31, 2021; accepted August 19, 2021

\begin{abstract}
Tris[2-(3'-cyanopropoxy)phenyl]phosphine oxide has been obtained via the alkylation of tris(2hydroxyphenyl)phosphine oxide with 4-bromobutyronitrile in the presence of $\mathrm{K}_{2} \mathrm{CO}_{3}$. The product structure has been elucidated by means of X-ray diffraction analysis. The terminal cyano groups in the obtained phosphine oxide have been converted into tetrazole rings via the click-reaction with $\mathrm{NH}_{4} \mathrm{~N}_{3}$ to give a new hybrid tripodal propeller ligand, tris $\left\{2-\left[3^{\prime}\right.\right.$-(tetrazol-5"-yl)propoxy]phenyl $\}$ phosphine oxide. Palladium(II) complexes of the prepared ligand and its short-linker analog, tris[2-(tetrazol-5'-ylmethoxy)phenyl]phosphine oxide, have been synthesized. Cytotoxicity of the ligands and their Pd(II) complexes has been studied.
\end{abstract}

Keywords: tetrazole tripodal ligands, palladium(II) complexes, crystal structure

DOI: $10.1134 / \mathrm{S} 1070363221100194$

The compounds bearing tetrazole fragments are interesting objects for coordination chemistry as ligands binding metal ions [1-3] and building blocks for the creation of novel materials: coordination polymers $[4,5]$ metal-organic frameworks (MOFs) [6], energetic materials [7], supercapacitors [8], and spin crossovers [9, 10].

Several tripodal ligands with tetrazole pendant groups have been described in the literature $[5,6,8,11-13]$. Their complexes with $d$ - and $f$-block elements have been suggested as light-emitting materials $[1,2]$ and contrasting agents [14].

At the same time, tetrazoles are of special interest for of medicinal chemistry, since they exhibit a wide range of biological activity, even being atypical for natural objects [15]. Tetrazoles are carboxylic acid bioisosters metabolically stable toward many biological transformations [16]. Tetrazoles possess antiangiogenic [17], antibacterial [18], anticancer [19, 20], fungicide [21], antimalarial [22], antituberculous [23], and antiviral [24] activity.

The use of triphenylphosphine oxide fragment as the core of a tripodal ligand can favor the complex formation with metal ions [25-29]. The combination of the $\mathrm{P}=\mathrm{O}$ fragment and tetrazole functional groups in hybrid ligands affords the compounds promising as ligands and biologically active molecules.

This study aimed to synthesize hybrid ligand $\mathbf{1}$ containing the phosphine oxide core and tetrazole side groups and to investigate cytotoxicity of the ligand and its palladium complex toward tumor cells. It was also interesting to compare ligand $\mathbf{1}$ to its analog $\mathbf{2}$ with a shorter linker [Bykhovskaya, O.V. et al., Russ. J. Gen., Chem., 2019, vol. 89, no. 12] (Scheme 1).

The target ligand 1 was prepared in two stages as follows. In the first stage, the reaction of phosphine oxide 3 [30] with 4-bromobutyronitrile in the presence of $\mathrm{K}_{2} \mathrm{CO}_{3}$ in anhydrous DMF gave tris[2-(3'-cyanopropoxy) phenyl]phosphine oxide 4 in $96.2 \%$ yield (Scheme 2 ). That compound was isolated as white crystalline powder, readily soluble in organic solvents $\left(\mathrm{CH}_{2} \mathrm{Cl}_{2}, \mathrm{CHCl}_{3}, \mathrm{DMF}\right.$, DMSO, etc.).

Composition and structure of the obtained trinitrile 4 were confirmed by the data of elemental analysis as well as IR and NMR $\left({ }^{1} \mathrm{H},{ }^{13} \mathrm{C}\right.$, and $\left.{ }^{31} \mathrm{P}\right)$ spectroscopy. IR spectrum of compound 4 contained the $v(\mathrm{C} \equiv \mathrm{N})$ bands at $2241 \mathrm{~cm}^{-1}$ and the $v(\mathrm{P}=\mathrm{O})$ bands at $1176 \mathrm{~cm}^{-1}$. The ${ }^{1} \mathrm{H}$ NMR spectrum of the solution in $\mathrm{CDCl}_{3}$ revealed the signals of the linker methylene protons as triplets or quintets at 1.6-4.1 ppm. The signals of the phenyl 
Scheme 1.

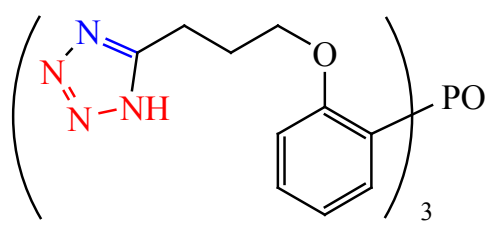

1<smiles>CC(C)c1ccccc1OCc1nnn[nH]1</smiles>

2

Scheme 2.

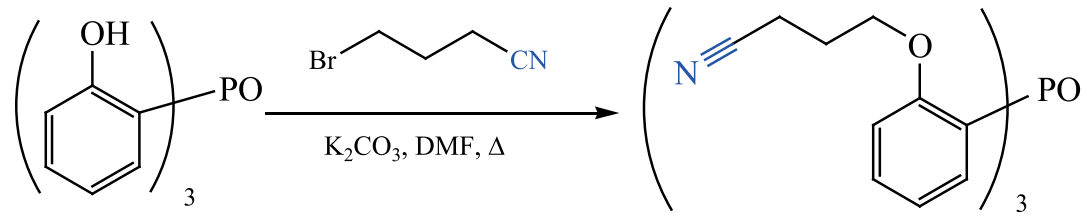

3

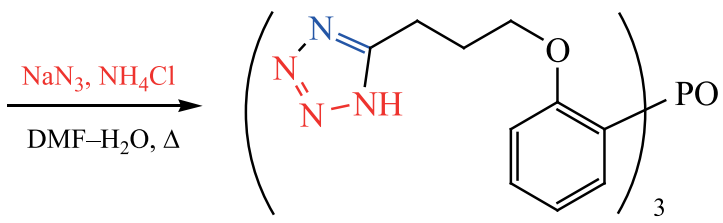

1

protons of the triphenylphosphine oxide core revealed chemical shifts and multiplicities typical of the related compounds [31] and appeared as doublets and triplets at $6.8-7.7 \mathrm{ppm}$. The ${ }^{13} \mathrm{C}$ NMR spectrum contained the singlet signals of the linker methylene groups at 13$66 \mathrm{ppm}$ and the $\mathrm{CN}$ group signals at $119.3 \mathrm{ppm}$. The signals of the carbon atoms of the triphenylphosphine oxide core appeared as doublets at 111-161 ppm with typical spin-spin coupling constants of $J_{\mathrm{PC}} 1.7$ to 111.2 Hz. The ${ }^{31} \mathrm{P}$ NMR spectrum contained a singlet at $28.1 \mathrm{ppm}$, typical of triarylphosphine oxides.

Molecular structure of tris[2-(3'-cyanopropoxy)phenyl]phosphine oxide 4 was confirmed by the X-ray diffraction analysis method (Fig. 1). Selected bond lengths are collected in Table 1 . The molecule of compound $\mathbf{4}$ was asymmetric, with two of three ortho-substituents located to the same side as the $\mathrm{P}=\mathrm{O}$ group with respect to the carbon atoms of the $\mathrm{POC}_{3}$ moiety and the third substituent was directed oppositely. The $\mathrm{O}^{1} \mathrm{P}^{1} \mathrm{C}^{22} \mathrm{O}^{4}$ angle corresponding to the substituent located oppositely to the phosphine oxide group equaled $-172.2(1)^{\circ}$, two other substituents forming the OPCO angles of 38.6(1) to $64.8(1)^{\circ}$. In the earlier described cases of tris(tetrazoles) and tris(alkanols) [31], the molecule conformation has been additionally stabilized by two $\mathrm{C}-\mathrm{H} \cdots \mathrm{O}(\mathrm{P})$ bonds. Molecule of compound 4 also contained two $\mathrm{O}-\mathrm{H} \cdots \mathrm{O}(\mathrm{P})$ intramolecular bonds formed by the substituents which were to the same side as the $\mathrm{P}=\mathrm{O}$ group (Fig. 1). The bond lengths and angles were typical of the earlier described phosphoryltris(2,1-phenylene)oxyalkenes $[27,29,31-33]$.

Table 1. Selected bond lengths and bond angles in the molecule of compound 4

\begin{tabular}{l|l|l|r}
\hline \multicolumn{1}{c|}{ Bond } & \multicolumn{1}{c|}{$d, \AA$} & \multicolumn{1}{c|}{ Angle } & \multicolumn{1}{c}{$\omega$, deg } \\
\hline $\mathrm{P}=\mathrm{O}$ & $1.4943(8)$ & $\mathrm{O}^{1} \mathrm{P}^{1} \mathrm{C}^{2} \mathrm{O}^{2}$ & $-65.0(1)$ \\
$\mathrm{P}-\mathrm{C}$ & $1.807(1)-1.809(1)$ & $\mathrm{O}^{1} \mathrm{P}^{1} \mathrm{C}^{12} \mathrm{O}^{3}$ & $-37.6(1)$ \\
$\mathrm{C}_{\mathrm{Ar}}-\mathrm{O}$ & $1.365(1)-1.366(1)$ & $\mathrm{O}^{1} \mathrm{P}^{1} \mathrm{C}^{22} \mathrm{O}^{4}$ & $-172.2(1)$ \\
$\mathrm{C}\left(\mathrm{H}_{2}\right)-\mathrm{O}$ & $1.435(1)-1.441(2)$ & & \\
$\mathrm{N} \equiv \mathrm{C}$ & $1.144(2)-1.146(2)$ & & \\
$\mathrm{NC}-\mathrm{C}\left(\mathrm{H}_{2}\right)$ & $1.467(2)-1.469(2)$ & & \\
\hline
\end{tabular}




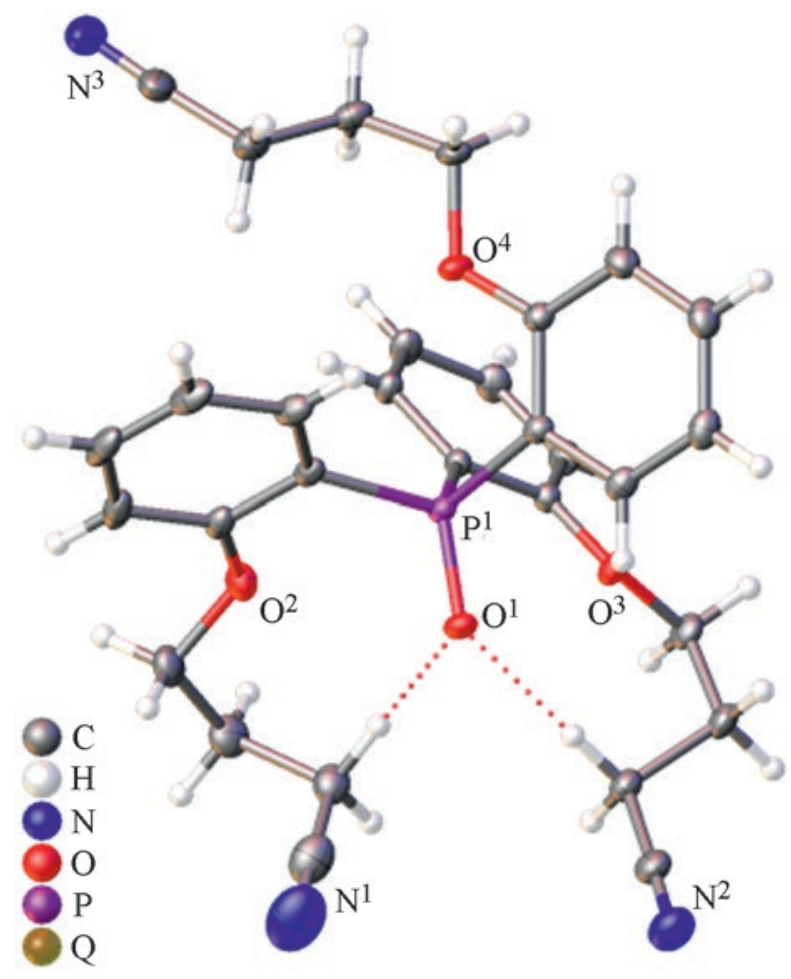

Fig. 1. General view of a molecule of tris [2-(3'-cyanopropoxy)phenyl]phosphine oxide 4 (CCDC 2085004) with the atoms displayed as thermal ellipsoids ( $p 50 \%)$. The $\mathrm{C}-\mathrm{H} \cdots \mathrm{O}$ intramolecular interactions are shown in dotted lines.

In the second stage, trinitrile 4 was introduced in the reaction with $\mathrm{NH}_{4} \mathrm{~N}_{3}$ prepared in situ from $\mathrm{NH}_{4} \mathrm{Cl}$ and $\mathrm{NaN}_{3}$, affording ligand $\mathbf{1}$ in $74.2 \%$ yield (Scheme 2). The product structure was elucidated by means of IR, Raman, and NMR $\left({ }^{1} \mathrm{H},{ }^{13} \mathrm{C}\right.$, and $\left.{ }^{31} \mathrm{P}\right)$ spectroscopy. Tris[2(tetrazol-5'-ylmethoxy)phenyl]phosphine oxide 2 has been prepared by us earlier [Bykhovskaya, O.V. et al.,
Russ. J. Gen., Chem., 2019, vol. 89, no. 12] using the same method from the corresponding cyano derivative [25].

IR and Raman spectra of ligand $\mathbf{1}$ were compared to those earlier described for ligand $\mathbf{2}$ with a known structure (Table 2). IR spectrum of compound 1 did not contain the bands of the starting trinitrile 4 at $2241 \mathrm{~cm}^{-1}$ $[v(\mathrm{C} \equiv \mathrm{N})]$ and $1176 \mathrm{~cm}^{-1}[v(\mathrm{P}=\mathrm{O})]$. Instead, the $v(\mathrm{P}=\mathrm{O})$ at $1086 \mathrm{~cm}^{-1}$ appeared in the spectrum as in the case of ligand 2, corresponding to a phosphoryl group involved in a bifurcate hydrogen bond. The spectra of ligands $\mathbf{1}$ and 2 were similar in the range of the $v(\mathrm{NH})$ vibrations. It should be noted that the spectrum of a solution of ligand 1 in DMSO $-d_{6}$ contained the $v(\mathrm{P}=\mathrm{O})$ band assigned to the phosphoryl group involved in hydrogen bond $\left(1157 \mathrm{~cm}^{-1}\right)$ and, in contrast to ligand $\mathbf{2}$, the band of the free $\mathrm{P}=\mathrm{O}$ group $\left(1185 \mathrm{~cm}^{-1}\right)$. That feature could be due to longer linker providing higher mobility of the pendant group.

Assignment of the ring vibrational frequencies was based on the calculation of the frequency and shape of normal vibrations in 5-substituted tetrazoles [34]. The absorption bands at $1600-1400 \mathrm{~cm}^{-1}$ mainly related to the $v(\mathrm{C}=\mathrm{N})$ and $v(\mathrm{~N}=\mathrm{N})$ vibrations overlapped with strong bands assigned to the phenoxy groups in the spectra of compounds $\mathbf{1}$ and $\mathbf{2}$ and thus could not be reliably detected. The band at $1480 \mathrm{~cm}^{-1}$ in the spectrum of ligand 1 (Table 2) was assigned mainly to the $v(\mathrm{C}-\mathrm{N})$ vibrations, the band at $1242 \mathrm{~cm}^{-1}$ corresponded to the $\mathrm{N}=\mathrm{N}$ bonds vibrations mixed with ring deformations, whereas the bands at 1124 and $1110 \mathrm{~cm}^{-1}$ were assigned to the $\delta(\mathrm{NH})$ deformational vibrations. The band at $1040 \mathrm{~cm}^{-1}$ was due to the out-of-plane $\rho(\mathrm{NH})$ vibrations mixed with the ring deformations, and the band at $990 \mathrm{~cm}^{-1}$ was assigned to the deformation of the cycle. Dissolution of ligand $\mathbf{1}$ in DMSO- $d_{6}$ led to the

Table 2. IR spectroscopy data for ligands 1, 2 and complexes 5, $\mathbf{6}$

\begin{tabular}{l|l|l|l|l}
\hline Compound & State/solvent & \multicolumn{1}{|c}{$v, \mathrm{~cm}^{-1}$} & $v(\mathrm{P}=\mathrm{O}), \mathrm{cm}^{-1}$ & \multicolumn{1}{|c}{$v(\mathrm{NH}), \mathrm{cm}^{-1}$} \\
\hline $\mathbf{1}$ & Solid sample & $1480,1466,1242,1124,1110,1043,986$ & $\sim 1090$ \\
& DMSO-d & $1248,1219,1127,1065$ & $\sim 2700 \mathrm{br}$ \\
$\mathbf{1} \cdot \mathrm{PdCl}_{2}(\mathbf{5})$ & Solid sample & $1474,1157^{\mathrm{a}}$ & $\mathrm{b}$ \\
$\mathbf{2}$ & Crystals & $1388,1246,1233,1118,1104,1041,1027$ & $\sim 1090$ & $3200-2100$ \\
& DMSO- $d_{6}$ & $1248,1219,1127,1065$ & $1155^{\mathrm{a}}$ & $\sim 2700 \mathrm{br}$ \\
$\mathbf{2} \cdot \mathrm{PdCl}_{2}(\mathbf{6})$ & Solid sample & $1396,1247,1123,1066, \sim 1030 \mathrm{br}$ & $\sim 1090$ & $3200-2200$ \\
\hline
\end{tabular}

${ }^{\mathrm{a}}$ Shoulder of the solvent absorption band at $1090 \mathrm{~cm}^{-1}$.

b Solvent absorption band. 
Table 3. ${ }^{1} \mathrm{H}$ NMR spectroscopy data for ligands $\mathbf{1}, 2$ and complexes $5,6(\delta, \mathrm{ppm})$

\begin{tabular}{|c|c|c|c|c|c|c|}
\hline Compound & $\mathrm{CH}_{2} \mathrm{CH}_{2} \mathrm{CH}_{2}$ & $\mathrm{CH}_{2}$-tetrazole & $\mathrm{CH}_{2} \mathrm{O}$ & $\mathrm{H}^{3}, \mathrm{H}^{5}$ & $\mathrm{H}^{4}, \mathrm{H}^{6}$ & ${ }^{31} \mathrm{P}\left\{{ }^{1} \mathrm{H}\right\}$ \\
\hline 1 & 1.76 br. s & 2.65 br. s & 3.87 br. $\mathrm{s}$ & $6.85-7.25 \mathrm{~m}$ & $7.42-7.60 \mathrm{~m}$ & 28.0 \\
\hline $2[4]$ & - & 5.37 br. s & - & $6.95 \mathrm{t}\left(\mathrm{H}^{5}\right), 7.32 \mathrm{~d} . \mathrm{d}\left(\mathrm{H}^{3}\right)$ & $\begin{array}{c}7.25 \mathrm{~d} . \mathrm{d}\left(\mathrm{H}^{6}\right) \\
7.60 \mathrm{t}\left(\mathrm{H}^{4}\right)\end{array}$ & 32.0 \\
\hline 5 & 1.74 br. s & $2.63 \mathrm{t}$ & a & $6.98 \mathrm{t}\left(\mathrm{H}^{5}\right), 7.08 \mathrm{~d} . \mathrm{d}\left(\mathrm{H}^{3}\right)$ & $\begin{array}{c}7.47 \mathrm{~d} . \mathrm{d}\left(\mathrm{H}^{6}\right) \\
7.53 \mathrm{t}\left(\mathrm{H}^{4}\right)\end{array}$ & 28.1 \\
\hline 6 & - & - & 5.38 br. s & $6.96 \mathrm{t}\left(\mathrm{H}^{5}\right), 7.34 \mathrm{t} . \mathrm{d}\left(\mathrm{H}^{3}\right)$ & $\begin{array}{l}7.26 \mathrm{~d} . \mathrm{d}\left(\mathrm{H}^{6}\right) \\
7.58 \mathrm{t}\left(\mathrm{H}^{4}\right)\end{array}$ & 29.5 \\
\hline
\end{tabular}

a The signal is overlapped by water signal.

disruption of the intermolecular hydrogen bonds and an intramolecular $\mathrm{P}=\mathrm{O} \cdots \mathrm{HN}$ hydrogen bond, as evidenced by the change in the $\delta(\mathrm{NH})$ and $v(\mathrm{P}=\mathrm{O})$ bands (Table 2 ).

${ }^{1} \mathrm{H}$ NMR spectrum of ligand $\mathbf{1}$ contained the signals of the linker methylene groups as three broadened singlets at $1.7-3.9 \mathrm{ppm}$. The aryl protons appeared as multiplets at 6.8-7.3 and 7.4-7.7 ppm. The ${ }^{1} \mathrm{H}$ NMR spectrum did not contain the signals of the $\mathrm{NH}$ group, this feature is typical of the tetrazoles spectra. The ${ }^{13} \mathrm{C}$ NMR spectrum revealed three singlet signals of the linker methylene groups at 19$67 \mathrm{ppm}$, a singlet of the tetrazole carbon atom at $155.67 \mathrm{ppm}$, and several doublets of the aryl carbon atoms at $113-160 \mathrm{ppm}$. The ${ }^{31} \mathrm{P}$ NMR spectrum contained a singlet at $28 \mathrm{ppm}$, typical of triarylphosphine oxides.

Palladium complexes with different heterocyclic compounds have been recognized for the antitumor activity [35]. In view of that, we synthesized the $1: 1$ complexes of the new ligand $\mathbf{1}(n=3)$ and the previously prepared ligand $\mathbf{2}(n=1)$ with $\mathrm{PdCl}_{2}$ : complexes $\mathbf{5}$ and $\mathbf{6}$, respectively (Scheme 3).

The complexes were isolated and characterized by means of elemental analysis as well as IR and NMR spectroscopy. According to the elemental analysis data, ligands $\mathbf{1}$ and $\mathbf{2}$ formed the $1: 1$ complexes with $\mathrm{PdCl}_{2}$.

Scheme 3.

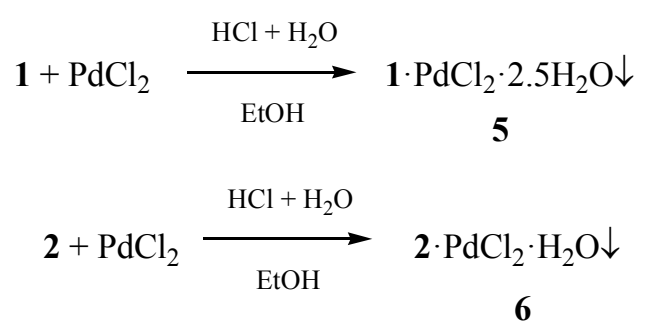

In contrast to the lanthanum complex with deprotonated ligand $\mathbf{2}$ described by us earlier [Bykhovskaya, O.V. et al., Russ. J. Gen., Chem., 2019, vol. 89, no. 12], the amino groups capable of hydrogen bonding were retained in complex $\mathbf{6}$, which could affect the coordination properties of the ligand. The $v(\mathrm{NH})$ bands of the palladium complex were changed in comparison with the free ligand spectrum: the maximum at $2700 \mathrm{~cm}^{-1}$ became weaker, and the second maximum appeared at $\sim 3100 \mathrm{~cm}^{-1}$, which could be assigned to weaker bound $\mathrm{NH}$ groups and the $v(\mathrm{OH})$ vibrations of bound water. The $v(\mathrm{P}=\mathrm{O})$ band, as in the ligand spectrum, appeared at about $1090 \mathrm{~cm}^{-1}$, evidencing preservation of the intramolecular hydrogen bons of the phosphoryl oxygen atom with two tetrazole rings, the ring vibrational bends being changed (Table 2). The Raman spectrum of complex 6 contained a band at $300 \mathrm{~cm}^{-1}$, which could be assigned to the $v_{\mathrm{s}}(\mathrm{Pd}-\mathrm{Cl})$ symmetric vibrations in the trans complex [36], hence palladium evidently coordinated two tetrazole rings in the trans configuration. In view of the $1: 1$ complex composition, it could be suggested that those tetrazole rings belonged to different molecules, and the dimers with one of the tetrazole rings acting as bridge were formed. Moreover, a water molecule could be bound to proton as well as nitrogen atom, linking the complexes.

The $v(\mathrm{P}=\mathrm{O})$ band in the spectrum of complex $\mathbf{5}$, as in the case of complex $\mathbf{6}$, was not shifted in comparison with the free ligand spectrum, hence it could be suggested that the node with the bifurcate hydrogen bond was retained. Position of the ring bands was slightly changed (Table 2 ). The $v_{\mathrm{s}}(\mathrm{Pd}-\mathrm{Cl})$ band at $299 \mathrm{~cm}^{-1}$ in the Raman spectrum was stronger than that in the spectrum of complex $\mathbf{6}$ and was also typical of trans geometry of the coordination plane. Overall, comparison of the vibrational spectra 
Table 4. Cytotoxicity of compounds 1, 2, 5, 6 (in vitro в MTT assay) ${ }^{\mathrm{a}}$

\begin{tabular}{l|c|c|c|c}
\hline \multirow{2}{*}{ Compound } & \multicolumn{4}{|c}{ IC50, $\mu \mathrm{M}$} \\
\cline { 2 - 5 } & A549 & HCT116 & HeLa & MCF7 \\
\hline $\mathbf{1}$ & $333.92 \pm 48.33$ & - & $350.14 \pm 22.01$ & $586.13 \pm 23.40$ \\
$\mathbf{2}$ & $382.17 \pm 20.84$ & - & $242.75 \pm 17.24$ & $444.00 \pm 15.60$ \\
$\mathbf{5}$ & - & - & - & - \\
$\mathbf{6}$ & $171.36 \pm 9.02$ & - & $141.17 \pm 5.68$ & $160.55 \pm 10.21$ \\
Camptothecin & $6.57 \pm 0.16$ & $5.68 \pm 0.28$ & $0.33 \pm 0.07$ & $24.30 \pm 2.87$ \\
\hline
\end{tabular}

a "_"_-no effect.

revealed structural similarity of the obtained palladium complexes.

Hence, the analysis of the vibrational spectra suggested the trans structure of complexes $\mathbf{5}$ and $\mathbf{6}$ with coordination of tetrazole rings of two ligands and preservation of the bifurcate intramolecular hydrogen bond with the phosphoryl group.

Complexes $\mathbf{5}$ and $\mathbf{6}$ were slowly dissolved in DMSO, seemingly without decomposition (as per the IR spectroscopy data).

${ }^{1} \mathrm{H}$ NMR spectrum of the solution of complex $\mathbf{5}$ contained a broad singlet of the central methylene group of the linker at $1.74 \mathrm{ppm}$ and a triplet of the $\mathrm{CH}_{2} \mathrm{~N}$ group protons at $2.63 \mathrm{ppm}$, whereas the signal of the $\mathrm{CH}_{2} \mathrm{O}$ group protons was masked with the water signal (Table 3 ). The aryl protons of complex $\mathbf{5}$ were observed as triplets at $6.98\left(\mathrm{H}^{5}\right), 7.53 \mathrm{ppm}\left(\mathrm{H}^{4}\right)$ and a doublet of doublets at $7.08\left(\mathrm{H}^{3}\right), 7.47 \mathrm{ppm}\left(\mathrm{H}^{6}\right)$.

The ${ }^{1} \mathrm{H}$ NMR spectrum of complex $\mathbf{6}$ contained a broad singlet of the $\mathrm{CH}_{2} \mathrm{O}$ group at $5.38 \mathrm{ppm}$ and the signals of the aromatic protons as triplets at $6.96\left(\mathrm{H}^{5}\right), 7.58 \mathrm{ppm}$ $\left(\mathrm{H}^{4}\right)$, triplet of doublets at $7.34 \mathrm{ppm}\left(\mathrm{H}^{3}\right)$, and doublet of doublets at $7.26 \mathrm{ppm}\left(\mathrm{H}^{6}\right)$. Comparison of the signals of protons for the ligands $\mathbf{1}, \mathbf{2}$ and complexes 5, $\mathbf{6}$ (Table 3 ) revealed that the complex formation with $\mathrm{PdCl}_{2}$ did not significantly change the ${ }^{1} \mathrm{H}$ NMR spectra as well as the ${ }^{31}$ P NMR spectra: the signal of the phosphorus atom was shifted downfield by $0.1-2.5 \mathrm{ppm}$. Those data evidenced no coordination with the $\mathrm{P}=\mathrm{O}$ group during the complex formation.

Ligands 1, 2 and their complexes with Pd(II) 5, 6 were tested for cytotoxicity against human cells cultures: A549 (lung carcinoma), HCT116 (colon carcinoma), $\mathrm{HeLa}$ (cervix of the uterus adenocarcinoma), and MCF7 (breast adenocarcinoma). The obtained data are collected in Table 4.

The tested compounds revealed weaker activity in comparison with the reference (Camptothecin). The palladium complex $\mathbf{5}$ was inactive towards the used cell cultures, and other compounds were inactive toward the HCT116 cells (colon carcinoma). Ligands $\mathbf{1}$ and $\mathbf{2}$ revealed almost equal cytotoxicity against the A549, HeLa, and MCF7 cells. At the same time, complex 6 revealed twice higher cytotoxicity against the A549, HeLa, and MCF7 in comparison with the starting ligand 2. Overall, the $\mathrm{Pd}(\mathrm{II})$ complex of ligand $\mathbf{2}$ with the short linker was the most active of the tested compounds.

In summary, we prepared tris[2-(3'-cyanopropoxy)phenyl]phosphine oxide, and its molecular structure was elucidated by means of X-ray diffraction analysis. A new tripodal ligand, tris $\left\{2-\left[3^{\prime}\right.\right.$-(tetrazol-5"'-yl)propoxy]phenyl $\}$ phosphine oxide, and its complex with $\mathrm{PdCl}_{2}$ were synthesized. Anticancer activity of the obtained compounds towards human cells was determined. The complex with tris[2-(tetrazol-5'-ylmethoxy)phenyl]phosphine oxide was found to be the most promising for further investigation.

\section{EXPERIMENTAL}

Organic solvents (reagent grade) were dried and purified via conventional methods [37]. Deuterated solvents: $\mathrm{CDCl}_{3}, \mathrm{DMSO}_{-} d_{6}$ (Acros), and 4-bromobutyronitrile (Aldrich, 97\%) were used as received. The salts: $\mathrm{PdCl}_{2}$ (reagent grade, Reakhim), sodium azide (Acros), and $\mathrm{NH}_{4} \mathrm{Cl}$ (reagent grade, Reakhim) were used as received. $\mathrm{K}_{2} \mathrm{CO}_{3}$ (reagent grade, Reakhim) was calcined prior to use. Tris(2-hydroxyphenyl)phosphine oxide $\mathbf{3}$ was synthesized as described elsewhere [30]. Tris[2-(tetrazol5'-ylmethoxy)phenyl]phosphine oxide 2 has been synthesized by us earlier. 
IR spectra of solid compounds $\mathbf{1}, \mathbf{5}$, and $\mathbf{6}$ were obtained using a Bruker Tensor 37 IR spectrometer (resolution $2 \mathrm{~cm}^{-1}$, range $4000-400 \mathrm{~cm}^{-1}$, KBr pellets or Nujol suspension). IR spectra of the solutions in DMSO- $d_{6}$ (c $0.04 \mathrm{M}, \mathrm{CaF}_{2}$ cuvettes with pathlength of $0.06 \mathrm{~mm}$ ) were recorded over the $4000-1100 \mathrm{~cm}^{-1}$ range. Raman spectra of the powders were recorded over the 3500 $100 \mathrm{~cm}^{-1}$ range using a Jobin-Ivon LabRAM 300 spectrometer equipped with a microscope and laser CCD detector. A $632.8 \mathrm{~nm} \mathrm{He}-\mathrm{Ne}$ laser (power not exceeding $2 \mathrm{~mW}$ ) was used as the excitation source. ${ }^{1} \mathrm{H}$, ${ }^{13} \mathrm{C}\left\{{ }^{1} \mathrm{H}\right\}$, and ${ }^{31} \mathrm{P}\left\{{ }^{1} \mathrm{H}\right\}$ NMR spectra of the solutions in $\mathrm{CDCl}_{3}$ and DMSO- $d_{6}$ were recorded using a Bruker Avance 400 instrument operating at 400.13, 100.61, and $161.98 \mathrm{MHz}\left({ }^{1} \mathrm{H},{ }^{13} \mathrm{C}\right.$, and ${ }^{31} \mathrm{P}$, respectively). The signals of residual protons and carbon atoms were used as internal references in the ${ }^{1} \mathrm{H}$ and ${ }^{13} \mathrm{C}$ NMR spectra, the accuracy of the chemical shifts determination being better than \pm 0.01 and $\pm 0.03 \mathrm{ppm}$, respectively. The chemical shifts in the ${ }^{31} \mathrm{P}$ NMR spectra were determined relative to $85 \%$ $\mathrm{H}_{3} \mathrm{PO}_{4}$ as external reference. The signals were assigned by comparison with the spectra of similar compounds [31]. Melting points were determined in a melting point apparatus using short Anschutz thermometers. The $\mathrm{C}, \mathrm{H}$, and $\mathrm{N}$ content was determined using a Carlo Erba 1106 instrument, the content of $\mathrm{P}$ was determined as described elsewhere [38].

Tris[2-(3'-cyanopropoxy)phenyl]phosphine oxide (4). Amixture of $0.74 \mathrm{~g}(0.005 \mathrm{~mol})$ of 4 -bromobutyronitrile, $2.1 \mathrm{~g}(0.015 \mathrm{~mol})$ of freshly calcined $\mathrm{K}_{2} \mathrm{CO}_{3}$, and $0.49 \mathrm{~g}$ (0.0015 mol) of tris(2-hydroxyphenyl)phosphine oxide 3 in $20 \mathrm{~mL}$ of anhydrous DMF was heated at $95^{\circ} \mathrm{C}$ with stirring during $4 \mathrm{~h}$. The solvent was removed, and $15 \mathrm{~mL}$ of $\mathrm{CH}_{2} \mathrm{Cl}_{2}$ was added to the dry residue; the obtained mixture was washed with water $(4 \times 15 \mathrm{~mL})$. The organic solution was dried with $\mathrm{Na}_{2} \mathrm{SO}_{4}$, and the solvent was removed. Light yellow oil crystallizing during keeping was obtained. The product was recrystallized from a $\mathrm{CH}_{2} \mathrm{Cl}_{2}-\mathrm{Et}_{2} \mathrm{O}$ mixture to obtain white crystalline substance. Yield $0.76 \mathrm{~g}(96.2 \%), \mathrm{mp} 159^{\circ} \mathrm{C}$. The crystals suitable for X-ray diffraction analysis were prepared via recrystallization from ethanol. IR spectrum $(\mathrm{KBr})$, $v, \mathrm{~cm}^{-1}: 2935 \mathrm{~m}, 2875 \mathrm{w}, 2241 \mathrm{~m}(\mathrm{C} \equiv \mathrm{N}), 1591 \mathrm{~s}, 1575$ m, $1481 \mathrm{~m}, 1465 \mathrm{~m}, 1441 \mathrm{vs}, 1383 \mathrm{~m}, 1282 \mathrm{vs}, 1253 \mathrm{~m}$, $1176 \mathrm{~m}(\mathrm{P}=\mathrm{O}), 1157 \mathrm{~m}, 1136 \mathrm{~m}, 1086 \mathrm{~m}, 1047 \mathrm{~s}, 953 \mathrm{~m}$, $933 \mathrm{~m}, 826 \mathrm{~m}, 772 \mathrm{~s}, 754 \mathrm{~m}, 739 \mathrm{~m}, 705 \mathrm{~m}, 615 \mathrm{w}, 558 \mathrm{~s}$, $530 \mathrm{~m}, 509 \mathrm{~m}, 414 \mathrm{~m} .{ }^{1} \mathrm{H}$ NMR spectrum $\left(\mathrm{CDCl}_{3}\right), \delta$, ppm: 1.77 quintet $\left(6 \mathrm{H}, \mathrm{CH}_{2} \mathrm{CH}_{2} \mathrm{CH}_{2},{ }^{3} J_{\mathrm{HH}} 6.0 \mathrm{~Hz}\right), 2.03 \mathrm{t}$ $\left(6 \mathrm{H}, \mathrm{CH}_{2} \mathrm{CN},{ }^{3} J_{\mathrm{HH}} 7.0 \mathrm{~Hz}\right), 4.02 \mathrm{t}\left(6 \mathrm{H}, \mathrm{CH}_{2} \mathrm{O},{ }^{3} J_{\mathrm{HH}}\right.$ $5.4 \mathrm{~Hz}), 6.98$ d. d $\left(3 \mathrm{H}, \mathrm{H}^{3},{ }^{3} J_{\mathrm{HH}} 8.4,{ }^{4} J_{\mathrm{PH}} 5.6 \mathrm{~Hz}\right)$, 7.10 t. d $\left(3 \mathrm{H}, \mathrm{H}^{5},{ }^{3} J_{\mathrm{HH}} 7.5,{ }^{4} J_{\mathrm{PH}} 2.1 \mathrm{~Hz}\right), 7.48$ d. d. d $\left(3 \mathrm{H}, \mathrm{H}^{6},{ }^{3} J_{\mathrm{PH}} 14.8,{ }^{3} J_{\mathrm{HH}} 7.6,{ }^{4} J_{\mathrm{HH}} 1.2 \mathrm{~Hz}\right), 7.57 \mathrm{t} . \mathrm{d}(3 \mathrm{H}$, $\left.\mathrm{H}^{4},{ }^{3} J_{\mathrm{HH}} 7.8,{ }^{4} \mathrm{~J}_{\mathrm{HH}} 1.4 \mathrm{~Hz}\right) .{ }^{13} \mathrm{C} \mathrm{NMR}$ spectrum $\left(\mathrm{CDCl}_{3}\right)$, $\delta_{\mathrm{C}}$, ppm: $13.79\left(\mathrm{CH}_{2} \mathrm{CH}_{2} \mathrm{CH}_{2}\right), 24.82\left(\mathrm{CH}_{2} \mathrm{CN}\right), 65.60$ $\left(\mathrm{CH}_{2} \mathrm{O}\right), 111.96 \mathrm{~d}\left(\mathrm{C}^{3},{ }^{3} \mathrm{~J}_{\mathrm{PC}} 6.5 \mathrm{~Hz}\right), 119.27(\mathrm{CN}), 119.48 \mathrm{~d}$ $\left(\mathrm{C}^{1},{ }^{1} J_{\mathrm{PC}} 111.2 \mathrm{~Hz}\right), 121.27 \mathrm{~d}\left(\mathrm{C}^{5},{ }^{3} J_{\mathrm{PC}} 12.8 \mathrm{~Hz}\right), 134.24 \mathrm{~d}$ $\left(\mathrm{C}^{6},{ }^{2} J_{\mathrm{PC}} 9.2 \mathrm{~Hz}\right), 134.44 \mathrm{~d}\left(\mathrm{C}^{4},{ }^{4} J_{\mathrm{PC}} 1.7 \mathrm{~Hz}\right), 160.32 \mathrm{~d}$ $\left(\mathrm{C}^{2},{ }^{2} J_{\mathrm{PC}} 1.9 \mathrm{~Hz}\right) .{ }^{31} \mathrm{P}\left\{{ }^{1} \mathrm{H}\right\}$ NMR spectrum $\left(\mathrm{CDCl}_{3}\right): \delta_{\mathrm{P}}$ 28.1 ppm. Found, \%: C 67.80; H 5.90; N 7.75; P 5.74. $\mathrm{C}_{30} \mathrm{H}_{30} \mathrm{~N}_{3} \mathrm{O}_{4} \mathrm{P}$. Calculated, \%: C 68.30; H 5.73; N 7.97; P 5.87.

Tris $\left\{2-\left[3^{\prime}\right.\right.$-(tetrazol-5"'-yl)propoxy]phenyl $\}$ phosphine oxide (1). $0.59 \mathrm{~g}(0.009 \mathrm{~mol})$ of $\mathrm{NaN}_{3}$ and $0.48 \mathrm{~g}(0.009 \mathrm{~mol})$ of $\mathrm{NH}_{4} \mathrm{Cl}$ were added at vigorous stirring to a solution of $0.53 \mathrm{~g}(0.001 \mathrm{~mol})$ of tris(3cyanopropoxyphenyl)phosphine oxide in $15 \mathrm{~mL}$ of anhydrous DMF at room temperature. The obtained suspension was kept at $130^{\circ} \mathrm{C}$ during $80 \mathrm{~h}$ and cooled to room temperature; $25 \mathrm{~mL}$ of water was then added. The obtained solution was extracted with $\mathrm{CHCl}_{3}(5 \times 10 \mathrm{~mL})$. The organic fractions were united, washed with water $(4 \times 10 \mathrm{~mL})$, and dried with $\mathrm{Na}_{2} \mathrm{SO}_{4}$. After removal of the solvent, the residue was a low-viscous oil which was recrystallized from diethyl ether. Yield $0.49 \mathrm{~g}$ (74.2\%), $\mathrm{mp} 155-156^{\circ} \mathrm{C}$. IR spectrum, $v, \mathrm{~cm}^{-1}: 3435$ br. $\mathrm{w}\left(\mathrm{H}_{2} \mathrm{O}\right)$, 2700 br. m (NH)), 1900 br. vs, 1592 vs, 1578 s, 1574 sh, 1567 sh, 1561 w. sh, 1477 vs, 1444 vs, 1388 m, 1280 vs, $1249 \mathrm{~m}, 1236 \mathrm{~m}, 1211 \mathrm{~s}, 1160 \mathrm{~m}, 1142 \mathrm{~s}, 1116 \mathrm{~m}, 1098 \mathrm{sh}$, 1089 s, 1050 s, 1040 s, 1027 sh, 1009 m, 925 w, 853 w, $802 \mathrm{sh}, 764$ s, $750 \mathrm{~m}, 730 \mathrm{~s}, 720 \mathrm{~s}, 698 \mathrm{~m}, 587 \mathrm{w}, 577 \mathrm{w}$, $563 \mathrm{~m}, 552 \mathrm{~m}, 532 \mathrm{~m}, 514 \mathrm{~m}, 487 \mathrm{~m}, 450 \mathrm{w}, 429 \mathrm{w}$. ${ }^{1} \mathrm{H}$ NMR spectrum (DMSO- $\left.d_{6}\right), \delta$, ppm: 1.76 br. s $(6 \mathrm{H}$, $\left.\mathrm{CH}_{2} \mathrm{CH}_{2} \mathrm{CH}_{2}\right), 2.65$ br. s $\left(6 \mathrm{H}, \mathrm{CH}_{2}\right.$-tetrazole), 3.87 br. s $\left(6 \mathrm{H}, \mathrm{CH}_{2} \mathrm{O}\right), 6.85-7.25 \mathrm{~m}\left(6 \mathrm{H}, \mathrm{H}^{3}, \mathrm{H}^{5}\right), 7.42-7.60 \mathrm{~m}$ $\left(6 \mathrm{H}, \mathrm{H}^{4}, \mathrm{H}^{6}\right) .{ }^{13} \mathrm{C}$ NMR spectrum (DMSO- $\left.d_{6}\right), \delta_{\mathrm{C}}, \mathrm{ppm}$ : $19.28\left(\mathrm{CH}_{2} \mathrm{CH}_{2} \mathrm{CH}_{2}\right), 26.52\left(\mathrm{CH}_{2}\right.$-tetrazole $), 66.62$ $\left(\mathrm{CH}_{2} \mathrm{O}\right), 113.03 \mathrm{~d}\left(\mathrm{C}^{3},{ }^{4} J_{\mathrm{PC}} 6.0 \mathrm{~Hz}\right), 119.28 \mathrm{~d}\left(\mathrm{C}^{1},{ }^{1} J_{\mathrm{PC}}\right.$ $115.8 \mathrm{~Hz}), 120.95 \mathrm{~d}\left(\mathrm{C}^{5},{ }^{3} J_{\mathrm{PC}} 12.5 \mathrm{~Hz}\right), 134.31 \mathrm{~d}\left(\mathrm{C}^{6}\right.$, $\left.{ }^{2} J_{\mathrm{PC}} 8.4 \mathrm{~Hz}\right), 134.68\left(\mathrm{C}^{4}\right), 155.67(\mathrm{C}=\mathrm{N}), 160.49 \mathrm{~d}\left(\mathrm{C}^{2}\right.$, $\left.{ }^{2} J_{\mathrm{PC}} 1.7 \mathrm{~Hz}\right) .{ }^{31} \mathrm{P}\left\{{ }^{1} \mathrm{H}\right\}$ NMR spectrum (DMSO- $\left.d_{6}\right): \delta_{\mathrm{P}}$ 28.0 ppm. Found, \%: C 54.22; H 5.28; N 25.02; P 4.71. $\mathrm{C}_{30} \mathrm{H}_{33} \mathrm{~N}_{12} \mathrm{O}_{4} \mathrm{P} \cdot 0.5 \mathrm{H}_{2} \mathrm{O}$. Calculated, \%: C 54.13; H 5.15; N 25.25; P 4.65.

Dichloro(tris $\left\{2-\left[3^{\prime}\right.\right.$-(tetrazol-5"'-yl)propoxy]phenyl $\}$ phosphine oxide)palladium(II) (5). $21.3 \mathrm{mg}$ of $\mathrm{PdCl}_{2}(0.12 \mathrm{mmol})$ was dissolved in $2 \mathrm{~mL}$ of $\mathrm{EtOH}$ on 
heating with addition of several drops of $6 \mathrm{M} \mathrm{HCl}$. The obtained solution was added dropwise with stirring to a solution of ligand 1 in $5 \mathrm{~mL}$ of EtOH; the formed light yellow precipitate was filtered off, washed with diethyl ether, and dried. Yield $0.10 \mathrm{~g}(95.2 \%), \mathrm{mp}>280^{\circ} \mathrm{C}$ (decomp.). IR spectrum (KBr), $v, \mathrm{~cm}^{-1}: 3446 \mathrm{br}, 3100$ 2200 (NH), 1900 br. w, 1590 vs, 1575 s, 1558 sh, 1543 sh, $1473 \mathrm{~s}, 1443 \mathrm{vs}, 1386 \mathrm{w}, 1282 \mathrm{vs}, 1245 \mathrm{~s}, 1166 \mathrm{~m}, 1141 \mathrm{~m}$, $1111 \mathrm{~m}, 1087 \mathrm{~m}(\mathrm{P}=\mathrm{O}), 1063$ sh, 1042 br. m, 942 br. m, 829 w, 758 m, 706 w, 557 m, 519 br. m. Raman spectrum, $v, \mathrm{~cm}^{-1}: 3071,2937,2885,1588,1481,1436,1404,1281$, 1247, 1164, 1143, 1040, 943, 825, 801, 670, 604, 349, 299. ${ }^{1} \mathrm{H}$ NMR spectrum (DMSO- $\left.d_{6}\right), \delta$, ppm: 1.74 br. s $\left(6 \mathrm{H}, \mathrm{CH}_{2} \mathrm{CH}_{2} \mathrm{CH}_{2}\right), 2.63 \mathrm{t}\left(6 \mathrm{H}, \mathrm{CH}_{2}\right.$-tetrazole, ${ }^{3} \mathrm{~J}_{\mathrm{HH}}$ $5.6 \mathrm{~Hz}), \mathrm{CH}_{2} \mathrm{O}$ signal was overlapped with the water signal, $6.98 \mathrm{t}\left(3 \mathrm{H}, \mathrm{H}^{5},{ }^{3} J_{\mathrm{HH}} 7.0 \mathrm{~Hz}\right), 7.08 \mathrm{~d} . \mathrm{d}\left(3 \mathrm{H}, \mathrm{H}^{3}\right.$, $\left.{ }^{3} J_{\mathrm{HH}} 8.4,{ }^{4} J_{\mathrm{PH}} 5.4 \mathrm{~Hz}\right), 7.47 \mathrm{~d} . \mathrm{d}\left(3 \mathrm{H}, \mathrm{H}^{6},{ }^{3} J_{\mathrm{PH}} 15.2,{ }^{3} J_{\mathrm{HH}}\right.$ $7.6 \mathrm{~Hz}), 7.53 \mathrm{t}\left(3 \mathrm{H}, \mathrm{H}^{4},{ }^{3} J_{\mathrm{HH}} 7.8 \mathrm{~Hz}\right) .{ }^{31} \mathrm{P}\left\{{ }^{1} \mathrm{H}\right\} \mathrm{NMR}$ spectrum $\left(\mathrm{CDCl}_{3}\right)$ : $\delta_{\mathrm{P}} 28.1 \mathrm{ppm}$. Found, \%: $\mathrm{C} 40.99 ; \mathrm{H} 4.16$; $\mathrm{N} \mathrm{18.67;} \mathrm{Cl} 7.84 ; \mathrm{P} 3.13 . \mathrm{C}_{30} \mathrm{H}_{33} \mathrm{Cl}_{2} \mathrm{~N}_{12} \mathrm{O}_{4} \mathrm{PPd} \cdot 2.5 \mathrm{H}_{2} \mathrm{O}$. Calculated, \%: C 40.99; H 4.36; N 19.12; Cl 8.07; P 3.52.

Dichloro(tris $\{2$-[3'-(tetrazol-5"'-yl)methoxy]phenyl\}phosphine oxide)palladium(II) (6). $29.8 \mathrm{mg}$ of $\mathrm{PdCl}_{2}(0.168 \mathrm{mmol})$ was dissolved in $2 \mathrm{~mL}$ of EtOH on heating with addition of several drops of $6 \mathrm{M}$. $\mathrm{HCl}$. The obtained solution was added dropwise with stirring to a solution of ligand $\mathbf{2}$ in $5 \mathrm{~mL}$ of $\mathrm{MeOH}$; the formed light yellow precipitate was filtered off, washed with diethyl ether, and dried. Yield $0.12 \mathrm{~g}(93.0 \%), \mathrm{mp}>240^{\circ} \mathrm{C}$ (decomp.). IR spectrum (KBr), v, $\mathrm{cm}^{-1}: 3446 \mathrm{br}, 3100$ 2200 (NH), 1900 br. w, 1591 vs, 1576 s, 1556 sh, 1476 vs, 1442 vs, 1282 vs, $1219 \mathrm{~m}, 1167 \mathrm{~m}, 1142 \mathrm{~m}, 1120 \mathrm{sh}$, $1090 \mathrm{~m}(\mathrm{P}=\mathrm{O}), 1064 \mathrm{sh}, 1041 \mathrm{sh}, 1028 \mathrm{~s}, 857 \mathrm{w}, 803 \mathrm{w}$, $758 \mathrm{~m}, 698 \mathrm{~m}, 557 \mathrm{~m}, 500 \mathrm{sh}$. Raman spectrum, $\mathrm{v}, \mathrm{cm}^{-1}$ : 3068, 2942, 1588, 1575, 1474, 1451, 1284, 1257, 1162, 1221, 1144, 1041, 851, 799, 662, 587, 357, 300. ${ }^{1} \mathrm{H}$ NMR spectrum (DMSO- $\left.d_{6}\right), \delta$, ppm: 5.38 br. s $\left(6 \mathrm{H}, \mathrm{CH}_{2}\right), 6.96 \mathrm{t}$ $\left(3 \mathrm{H}, \mathrm{H}^{5},{ }^{3} J_{\mathrm{HH}} 7.0 \mathrm{~Hz}\right), 7.26$ d. d $\left(3 \mathrm{H}, \mathrm{H}^{6},{ }^{3} \mathrm{~J}_{\mathrm{PH}} 14.8,{ }^{3} \mathrm{~J}_{\mathrm{HH}}\right.$ $7.2 \mathrm{~Hz}), 7.34$ t. d $\left(3 \mathrm{H}, \mathrm{H}^{3},{ }^{3} J_{\mathrm{HH}} 8.4,{ }^{4} J_{\mathrm{PH}} 6.0 \mathrm{~Hz}\right), 7.58 \mathrm{t}$ $\left(3 \mathrm{H}, \mathrm{H}^{4},{ }^{3} J_{\mathrm{HH}} 7.6 \mathrm{~Hz}\right) .{ }^{31} \mathrm{P}\left\{{ }^{1} \mathrm{H}\right\}$ NMR spectrum $\left(\mathrm{CDCl}_{3}\right)$ : $\delta_{\mathrm{P}} 29.5$ ppm. Found, \%: C 37.51; H 3.00; N 21.52; Cl 8.79; P 3.77. $\mathrm{C}_{24} \mathrm{H}_{21} \mathrm{Cl}_{2} \mathrm{~N}_{12} \mathrm{O}_{4} \mathrm{PPd} \cdot \mathrm{H}_{2} \mathrm{O}$. Calculated, \%: C 37.54; H 3.02; N 21.89; Cl 9.23; P 4.03.

$\mathrm{X}$-ray diffraction analysis of tris[2-(3'-cyanopropoxy)phenyl]phosphine oxide 4 . Single crystals of compound $\mathbf{4}$ were obtained via crystallization from ethanol. Intensity of 309409 reflections was measured using a Bruker Apex II CCDc diffractometer with graphite monochromator $\left(\mathrm{Mo} K_{\alpha}\right.$ radiation, $\lambda 0.71073 \AA$, $2 \theta$-scanning) at $120.0(2) \mathrm{K}$. Crystallographic data for compound 4: $\mathrm{C}_{30} \mathrm{H}_{30} \mathrm{~N}_{3} \mathrm{O}_{4} \mathrm{P}, M$ 527.54, monoclinic crystals, space group $P 2_{1} / n, a 11.0546(4), b$ 14.3483(5), c 17.0770(6) $\AA, \beta$ 96.596(1) ${ }^{\circ}, V$ 2690.7(2) $\AA^{3}, Z 4$, $d_{\text {calc }} 1.302 \mathrm{~g} / \mathrm{cm}^{3}, \mu 0.143 \mathrm{~mm}^{-1}, 12087$ independent reflections $\left(R_{\text {int }} 0.0394\right), 8661$ observed reflections, final convergence factors $R_{1}[I>2 \sigma(I)] 0.047, w R\left(F^{2}\right)$ 0.130 and GOF 1.01. The structure was solved using SHELXT software [39] and refined via full-matrix least squares method over $F^{2}$. The non-hydrogen atoms were refined under anisotropic approximation, the positions of the hydrogen atoms were calculated, and the hydrogen atoms were included in the refinement using the rider model with $U_{\text {iso }}(\mathrm{H})=1.2 U_{\text {eq }}(\mathrm{C})$. The calculations were performed using SHELXL2014 [40] and OLEX2 [41] software package. CCDC 2085004 contains additional crystallographic information relevant to this paper. These data are available free of charge via http://www.ccdc.cam. ac.uk/structures/.

Cytotoxicity (in vitro MTT-test). The A549 and HCT116 human cells were cultivated in DMEM medium, and MCF7 and HeLa human cells were cultivated in EMEM medium with addition of $10 \%$ fetal calf serum, $2 \mathrm{mM}$ of glutamine, and $1 \%$ gentamicin as antibiotic at $37^{\circ} \mathrm{C}$ under humid $\mathrm{CO}_{2}$ atmosphere $(5 \%)$. The cells of adhesion cultures A549, HCT116, MCF7, and HeLa were seeded at concentration of $1 \times 10^{4}$ cells $/ 200 \mu \mathrm{L}$ in a 96-well plate and cultivated at $37^{\circ} \mathrm{C}$ under humid atmosphere with $5 \%$ of $\mathrm{CO}_{2}$. Upon $24 \mathrm{~h}$ of incubation, 100 to $1.56 \mathrm{pM}$ of the studied compounds was added to the cell cultures, and they were cultivated for further $72 \mathrm{~h}$ under the same conditions. The experiments were run in triplicate at each concentration. The compounds were dissolved in DMSO, final concentration of which in the well did not exceed $1 \%$ and was not toxic for the cells. Pure solvent (final concentration 1\%) was added to the reference cells. Upon the incubation, $20 \mu \mathrm{L}$ of MTT $(5 \mathrm{mg} / \mathrm{mL}$ ) was added to each well, and the plate was incubated during $2 \mathrm{~h}$. The medium was then removed from the wells, and $100 \mu \mathrm{L}$ of DMSO was added to each well for dissolution of the formed formazan crystals. Absorbance at $536 \mathrm{~nm}$ was measured using a Cytation 3 plate scanner (BioTeklnstruments, Inc). The value of the concentration inducing $50 \%$ inhibition of the cells growth (IC50, $\mu \mathrm{M}$ ) was determined from the dose-dependent curves using OriginPro 9.0 software. 


\section{AUTHOR INFORMATION}

T.V. Baulina, ORCID: https://orcid.org/0000-0003-08210056

I.Yu. Kudryavtsev, ORCID: https://orcid.org/0000-00024324-8001

V.K. Brel, ORCID: https://orcid.org/0000-0003-4645-3251

\section{FUNDING}

This study was financially supported by the Russian Science Foundation (project no. 20-13-00329). Elemental analysis and recording of NMR, IR, and Raman spectra were financially supported by the Ministry of Science and Higher Education of the Russian Federation and performed using the equipment of the Center for Molecular Structure Studies, Nesmeyanov Institute of Organoelement Compounds, RAS.

\section{CONFLICT OF INTEREST}

V.K. Brel is a member of the Editorial Board of Russian Journal of General Chemistry. No conflict of interest was declared by other authors.

\section{OPEN ACCESS}

This article is licensed under a Creative Commons Attribution 4.0 International License, which permits use, sharing, adaptation, distribution and reproduction in any medium or format, as long as you give appropriate credit to the original author(s) and the source, provide a link to the Creative Commons license, and indicate if changes were made. The images or other third party material in this article are included in the article's Creative Commons license, unless indicated otherwise in a credit line to the material. If material is not included in the article's Creative Commons license and your intended use is not permitted by statutory regulation or exceeds the permitted use, you will need to obtain permission directly from the copyright holder. To view a copy of this license, visit http://creativecommons.org/licenses/by/4.0/.

\section{REFERENCES}

1. Gaponik, P.N., Voitekhovich, S.V., and Ivashkevich, O.A., Russ. Chem. Rev., 2006, no. 75, p. 507. https://doi.org/10.1070/RC2006v075n06ABEH003601

2. Popova, E.A., Trifonov, R.E., and Ostrovskii, V.A., Arkivoc, 2012, vol. 45. https://doi.org/10.3998/ark.5550190.0013.102

3. Massi, M., Stagni, S., and Ogden, M.I., Coord. Chem. Rev., 2018, vol. 375, p. 164.

https://doi.org/10.1016/j.ccr.2017.11.017
4. Aromi, G., Barrios, L.A., Roubeau, O., Gamez, P., Coord. Chem. Rev., 2011, vol. 255, p. 485. https://doi.org/10.1016/j.ccr.2010.10.038

5. Feng, Y., Cai, S.-L., Gao, Y., and Zheng, S.-R., J. Solid State Chem., 2018, vol. 265, p. 64. https://doi.org/10.1016/j.jssc.2018.05.031

6. He, H., Song, Y., Sun, F., Zhao, N., and Zhu, G., Cryst. Growth Des., 2015, vol. 15, p. 2033. https://doi.org/10.1021/acs.cgd.5b00229

7. Haiges, R. and Christe, K.O., Inorg Chem., 2013, vol. 52, p. 7249 . https://doi.org/10.1021/ic400919n

8. Wang, J., Deng, S.-Q., Zhao, T.-T., Zheng, S.-R., Cai, S.-L., Fan, J., and Zhang, W.-G., Dalton Trans., 2020, vol. 4, p. 12150. https://doi.org/10.1039/d0dt01666g

9. Zeni, W., Seifried, M., Knoll, C., Welch, J.M., Giester, G., Stöger, B., Artner, W., Reissner, M., Müller, D., and Weinberger, P., Dalton Trans., 2020, vol. 49, p. 17183. https://doi.org/10.1039/d0dt03315d

10. Kusz, J., Gütlich, P., and Spiering, H., Top. Curr. Chem., 2004, vol. 234, p. 129. https://doi.org/10.1007/b95415

11. Wei, W., Wang, G., Zhang, Y., Jiang, F., Wu, M., and Hong, M., Chem. Eur. J., 2011, vol. 17, p. 2189. https://doi.org/10.1002/chem.201002246

12. Białońska, A., Bronisz, R., Rudolf, M.F., and Weselski, M., Inorg. Chem., 2012, vol. 51, p. 237. https://doi.org/10.1021/ic201535x

13. Boland, Y., Hertsens, P., Marchand-Brynaert, J., and Garcia, Y., Synthesis, 2006, vol. 9, p. 1504. https://doi.org/10.1055/s-2006-926439

14. Giraud, M., Andreiadis, E.S., Fisyuk, A.S., Demadrille, R., Pécaut, J., Imbert, D., and Mazzanti, M., Inorg. Chem., 2008, vol. 47, p. 3952.

https://doi.org/10.1021/ic8005663

15. Ostrovskii, V.A., Trifonov, R.E., and Popova, E.A., Russ. Chem. Bull., 2012, vol. 61, p. 768. https://doi.org/10.1007/s11172-012-0108-4

16. Zou, Y., Liu, L., Liu, J., and Liu, G., Future Med. Chem., 2020, vol. 12, p. 91. https://doi.org/10.4155/fmc-2019-0288

17. Li, Y., Pasunooti, K.K., Li, R.J., Liu, W., Head, S.A., Shi, W.Q., and Liu, J.O., J. Med. Chem., 2018, vol. 61, p. 11158. https://doi.org/10.1021/acs.jmedchem.8b01252 
18. Gao, F., Xiao, J., and Huang, G., Eur. J. Med. Chem., 2019, vol. 184, p. 111744. https://doi.org/10.1016/j.ejmech.2019.111744

19. Zhang, J.Y., Wang, S., Ba, Y.Y., and Xu, Z., Eur. J. Med. Chem., 2019, vol. 178, p. 341. https://doi.org/10.1016/j.ejmech.2019.05.071

20. Popova, E.A., Protas, A.V., and Trifonov, R.E., AntiCancer Agents Med. Chem., 2018, vol. 17, p. 1856. https://doi.org/10.2174/1871520617666170327143148

21. Wang, S.Q., Wang, Y.F., and Xu, Z., Eur. J. Med. Chem., 2019, vol. 170, p. 225. https://doi.org/10.1016/j.ejmech.2019.03.023

22. Gao, C., Chang, L., Xu, Z., Yan, X.-F., Ding, C., Zhao, F., Wu, X., and Feng, L.-S., Eur. J. Med. Chem., 2019, vol. 163, p. 404. https://doi.org/10.1016/j.ejmech.2018.12.001

23. Roh, J., Karabanovich, G., Vlčková, H., Carazo, A., Němeček, J., Sychra, P., Valášková, L., Pavliš, O., Stolaříková, J., Klimešová, V., Vávrová, K., Pávek, P., and Hrabálek, A., Bioorg. Med. Chem., 2017, vol. 25, p. 5468. https://doi.org/10.1016/j.bmc.2017.08.010

24. Zhan, P., Li, Z., Liu, X., and Clercq, D.E., Mini Rev. Med. Chem., 2009, vol. 9, p. 1014. https://doi.org/10.2174/138955709788681618

25. Kudryavtsev, I.Yu., Baulina, T.V., Pasechnik, M.P., Matveev, S.V., Petrovskii, P.V., and Nifant'ev, E.E., Russ. Chem. Bull., 2013, vol. 62, no. 4, p. 1086. https://doi.org/10.1007/s11172-013-0146-6

26. Kudryavtsev, I.Yu., Baulina, T.V., Pasechnik, M.P., Matveev, S.V., and Matveeva, A.G., Phosphorus, Sulfur, Silicon, Relat. Elem., 2014, vol. 189, nos. 7-8, p. 946. https://doi.org/10.1080/10426507.2014.904865

27. Matveeva, A.G., Kudryavtsev, I.Yu., Pasechnik, M.P., Vologzhanina, A.V., Baulina, T.V., Vavina, A.V., Sukat, G.Ya., Matveev, S.V., Godovikov, I.A., Turanov, A.N., Karandashev, V.K., and Brel, V.K., Polyhedron, 2018, vol. 142, p. 71. https://doi.org/10.1016/j.poly.2017.12.025

28. Turanov, A.N., Matveeva, A.G., Kudryavtsev, I.Yu., Pasechnik, M.P., Matveev, S.V., Godovikova, M.I., Baulina, T.V., Karandashev, V.K., and Brel, V.K., Polyhedron, 2019, vol. 161, p. 276. https://doi.org/10.1016/j.poly.2019.01.036

29. Kudryavtsev, I.Y., Bykhovskaya, O.V., Matveeva, A.G., Baulina, T.V., Pasechnik, M.P., Matveev, S.V., Vologzhanina, A.V., Turanov, A.N., Karandashev, V.K., and
Brel, V.K., Monat. Chem., 2020, vol. 151, p. 1705. https://doi.org/10.1007/s00706-020-02702-6

30. Kudryavtsev, I.Yu., Baulina, T.V., Khrustalev, V.N., Petrovskii, P.V., Pasechnik, M.P., and Nifant'ev, E.E., Doklady Chem., 2013, vol. 448, no. 2, p. 55. https://doi.org/10.1134/S0012500813020092

31. Baulina, T.V., Pasechnik, M.P., Kudryavtsev, I.Yu., Bykhovskaya, O.V., Sukat, G.Ya., Smol'yakov, A.F., Anikina, L.V., and Brel, V.K., J. Mol. Struct., 2020, vol. 1217 , p. 128324.

https://doi.org/10.1016/j.molstruc.2020.128324

32. Livant, P.D., Mao, J., and Webb, T.R., Acta Crystallogr., 1996, vol. 52, p. 2924.

https://doi.org/10.1107/S0108270196008906

33. Baulina, T.V., Kudryavtsev, I.Y., Smolyakov, A.F., Pasechnik, M.P., and Brel, V.K., Heteroatom. Chem., 2018, p. e21454.

https://doi.org/10.1002/hc.21454.

34. Matveeva, N.A., Sushko, N.I., Makarevich, N.I., Gaponik, P.N., Ivashkevich, O.A., and Koren', A.O., Zh. Prikl. Spektr., 1992, vol. 57, nos. 5-6, p. 442.

35. Al-Janabi, A.S.M., Alheety, M.A., Al-Samrai, O.A.Y., Shaaban, S., Kibar, B., and Cacan, E., Inorg. Chem. Commun., 2020, vol. 121, p. 108193. https://doi.org/10.1016/j.inoche.2020.108193

36. Nakamoto, K., Infrared and Raman Spectra of Inorganic and Coordination Compounds, Hoboken: J. Wiley \& Sons, Inc., 2009, pt. B.

37. Armarego, W.L.F., Purification of Laboratory Chemicals, Amsterdam: Elsevier, 2017. https://doi.org/10.1016/B978-0-12-805457-4.50008-2

38. Gel'man, N.E., Terent'eva, E.A., Shanina, T.M., and Kiparenko, L.M., Metody kolichestvennogo organicheskogo elementnogo mikroanaliza (Quantitative Organic Elemental Microanalysis Methods), Moscow: Khimija, 1987, p. 296.

39. Sheldrick, G.M., Acta Crystalogr. (A), 2015, vol. 71 , no. 1 , p. 3.

https://doi.org/10.1107/S2053273314026370

40. Sheldrick, G.M., Acta Crystallogr. (C), 2015 , vol. 71 , no. 1 , p. 3 . https://doi.org/10.1107/S2053229614024218

41. Dolomanov, O.V., Bourhis, L.J., Gildea, R.J., Howard, J.A.K., and Puschman, H., J. Appl. Cryst., 2009, vol. 42, no. 2, p. 339.

https://doi.org/10.1107/S0021889808042726 